\title{
Socioeconomic Conditions and Landowners' Perception Affect the Intention to Restore Polylepis Forests in the Central Andes of Peru
}

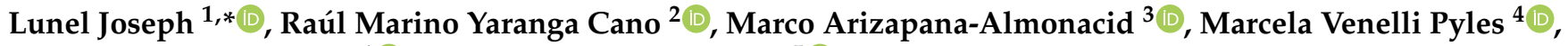 \\ Flávia Freire de Siqueira ${ }^{1}\left(\mathbb{B}\right.$ and Eduardo van den Berg ${ }^{5}$ (I)
}

1 Forest Engineering Graduate Program, Federal University of Lavras, Avenida Doutor Sylvio Menicucci, 3037, Lavras, Minas Gerais 37200-900, Brazil; flaviafreirelv@gmail.com

2 Centro de Investigación en Alta Montaña, Universidad Nacional del Centro del Perú, Carretera Central, 3909, Huancayo, Junin 12150, Peru; yarangacano@gmail.com

3 Grupo de Investigación en Sensoramiento Remoto y Ecología de Montaña, Universidad Nacional Autónoma de Huanta, Jr. Razuhuillca, 624, Huanta 0512, Peru; marizapana@gmail.com

4 Applied Ecology Graduate Program, Federal University of Lavras, Avenida Doutor Sylvio Menicucci, 3037, Lavras, Minas Gerais 37200-900, Brazil; marcelav.pyles@gmail.com

5 Department of Ecology and Conservation, Federal University of Lavras, Avenida Doutor Sylvio Menicucci, 3037, Lavras, Minas Gerais 37200-900, Brazil; evandenb@ufla.br

* Correspondence: joseph.lunel8@gmail.com

check for updates

Citation: Joseph, L.; Yaranga Cano, R.M.; Arizapana-Almonacid, M.;

Venelli Pyles, M.; Freire de Siqueira

F.; van den Berg, E. Socioeconomic

Conditions and Landowners'

Perception Affect the Intention to

Restore Polylepis Forests in the Central

Andes of Peru. Forests 2021, 12, 118.

https://doi.org/10.3390/f12020118

Received: 31 October 2020

Accepted: 23 December 2020

Published: 22 January 2021

Publisher's Note: MDPI stays neutral with regard to jurisdictional clai$\mathrm{ms}$ in published maps and institutional affiliations.

Copyright: $\odot 2021$ by the authors. Licensee MDPI, Basel, Switzerland. This article is an open access article distributed under the terms and conditions of the Creative Commons Attribution (CC BY) license (https:// creativecommons.org/licenses/by/ $4.0 /)$.
Abstract: Research Highlights: Families more dependent on crops as the main source of income of properties have a greater intention of restoring Polylepis forest areas. However, this intention reduces with the increase of family dependence on subsistence products supplied by Polylepis forests. Properties where the chances of restoration of Polylepis forests are greater are those where the educational and technical level is better. Objectives: We aimed to comprehend which socioeconomic factors of rural properties and families' perception were determinant for the intention to restore Polylepis forests in the Central Andes region of Peru. Material and Methods: We collected data through visits and the application of questionnaires. We selected 13 rural communities in the Tulumayo River Basin. We randomly sampled 10 to 20 families in each community, depending on its size, totaling 200 families. We used generalized linear mixed model (GLMM) to test which variables affect the intention to restore the forest. Results: When crops are the main source of income in the property, the families have more intention to restore Polylepis areas, on the other hand, when Polylepis forests are an important source of products for the family subsistence, the intention to restore forests reduces, indicating that higher technological status has a positive impact on restoration. The perception that Polylepis forests are important for the existence of water sources had a positive impact on the families' intention to restore the areas. However, the perception that Polylepis forests are important for native flora persistence had a negative impact on the intention to restore their areas. Conclusions: Our results showed that investment in improving the productivity of the properties and in the education of their landowners should increase the success of eventual programs for restoration of Polylepis forests.

Keywords: forest restoration; Andean forest; human impact; water conservation; education impact

\section{Introduction}

The mountain forests are deemed extremely fragile to climate change [1-3]. They are also intensely threatened by over-exploitation, soil erosion, fire, and farming expansion [4]. However, these forest ecosystems have important ecosystem functions and play key roles in providing goods and ecosystem services [5]. These forests mitigate carbon dioxide emissions, reduce soil erosion [6-9], and improve soil nutrients cycling [6-10]. In addition, 
these forests offer a variety of wood and non-wood products used by the human populations $[6,11,12]$. Finally, they promote precipitation interception and water infiltration in the soil, thus being important for supplying water to domestic, agricultural, and industrial uses $[2,13]$.

The Andean forests are considered biodiversity refuges and have high levels of endemism [14]. Such forests exist in an extensive latitudinal gradient, from the Cordillera de Mérida in Venezuela to the Sierras dos Comechingones in Central Argentina $[15,16]$. These mountain ecosystems present an unconventional water dynamic [17], where the fog and light rain interception by the forest [18] represents an important additional water supply to the ecosystem $[6,17,19]$. In some cases, the water dripping resulting from this interception represents the largest water supply to the ecosystem, being even more important during the period with lower precipitation $[6,17,19]$.

The Polylepis species present greater abundance in the Andean forests mainly above $3500 \mathrm{~m}$ of altitude [20]. At the global level, Polylepis tarapacana, for example, is the tree species that reaches the highest altitude, with some individuals found above $5000 \mathrm{~m}$ [21,22]. The Andean forests at high elevation are typically dominated by species of the Polylepis, while at lower altitudes other genera such as Weinmannia, Alnus, Clethra, Escallonia, Clusia, and Maytenus are also conspicuous [23,24]. Because of the high altitudes, the Polylepis forests are subject to wide daytime temperature fluctuations, usually with daily differences of 20-30 ${ }^{\circ} \mathrm{C}$, frequently with the occurrence of frosts at night. Most species of Polylepis have adaptations to low temperatures, which can be morphological, such as thick shells and rhytidome, or physiological, such as resistance to freezing [4,25].

The Polylepis forests in the Central Andes, besides the impact of fire and climate change, are intensely threatened by farming activities [6,12,21,26-29], wood exploitation [12,27-29], substitution by exotic species, and infrastructure development such as roads, housing developments, and mining [12,27,29]. In the Peruvian Central Andes region, for example, in the Laraos district, the forest disturbances caused by the human population of the Yauyos culture occur for approximately 500 years [29,30]. Due to these multiple threats, 13 of the 28 species of Polylepis in the high Andean mountain range [31-33] are considered vulnerable by the International Union for Conservation of Nature (IUCN) [34] and measures for their conservation and restoration are essential [35].

Currently, most of the existing information about these forests are of observational character, of experimental nature, or extracted from plant population and plant community modeling. No study investigated or evaluated explicitly how the human populations interact with these forests, in terms of conservation or degradation. The absence of this kind of information is particularly problematic for restoration since it is fundamental to establish forest in private lands to understand what helps and what curbs the landowners to take such a step [36]. Such knowledge is fundamental to promote public policies that target the restoration of Polylepis forests in the Andes [37].

Based on this perspective we aimed this study to the following questions: (i) Which socioeconomic factors of the rural properties influence the intention of the families to restore the Polylepis forests in the Peruvian Central Andes? (ii) How families' perceptions of these forests condition their intention to restore them?

Our central hypotheses, following the questions, were: (i) the importance of the forest as a source of products to the rural families positively influences their intention to restore the Polylepis forests in their properties; (ii) a positive perception of Polylepis forests for provision of the water increases the owners' intention to restore the forest in their properties.

\section{Material and Methods}

\subsection{Characterization of the Study Area}

Our study was performed in the Tulumayo River Basin. The basin is located in the Junin Department in the center of Peru (Figure 1) (Central coordinates $11^{\circ} 00^{\prime} 23^{\prime \prime} \mathrm{S}$, $\left.75^{\circ} 51^{\prime} 04^{\prime \prime} \mathrm{W}\right)$. The region is inserted in the Peruvian Central Andes and is characterized as 
a potential area for the occurrence of Polylepis forests [38]. In addition, this basin is an area where Polylepis forests still persist in Junin, while in other areas they are scarcer or simply do not exist anymore.
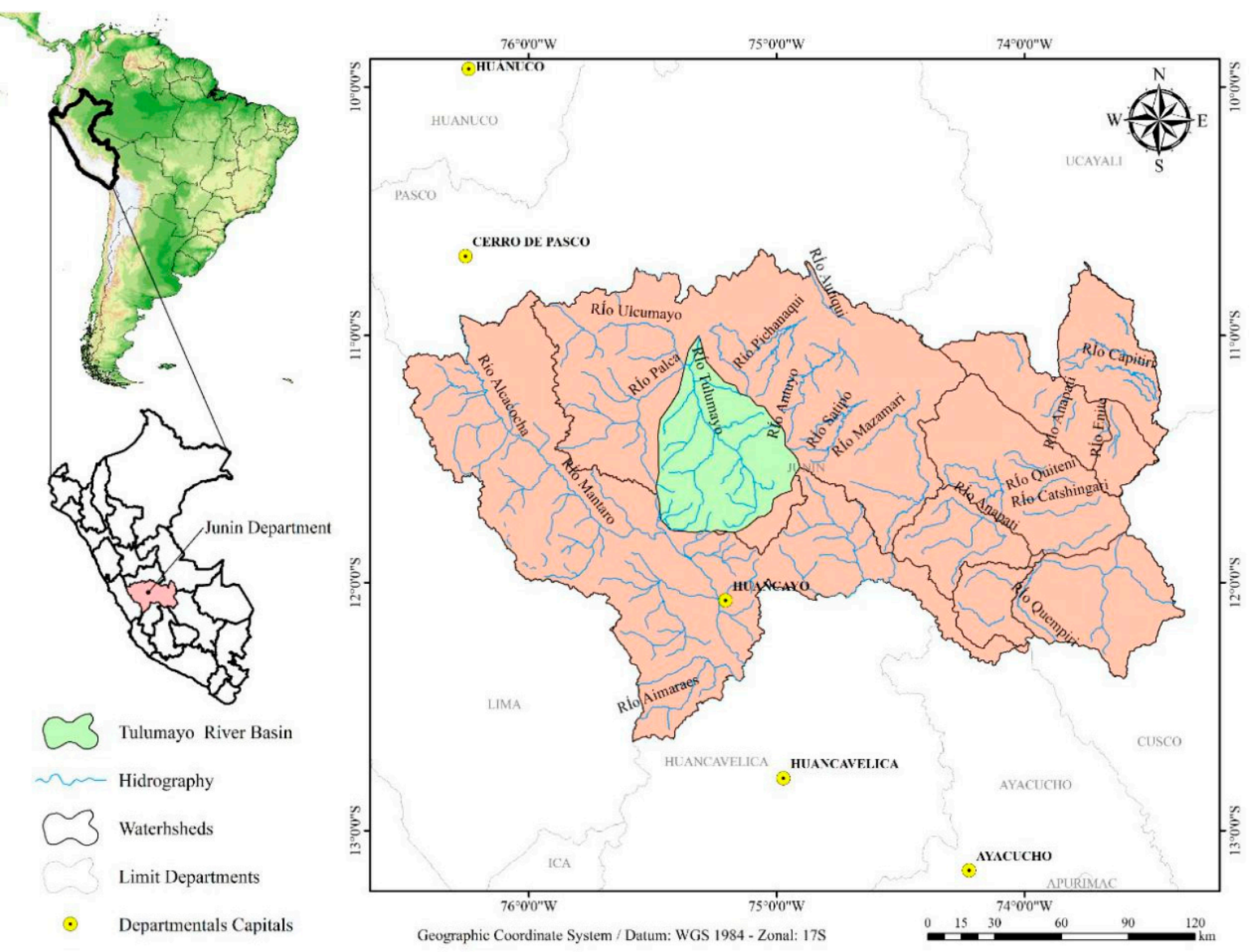

Figure 1. Location of the Tulumayo River Basin, Junin Department in the Peruvian Central Andes. Elaboration: Luciano Cavalcante de Jesus França. Source: GEO GPS PERÚ [38].

The Tulumayo River Basin presents a very rugged physiographic structure with the presence of mountain peaks, hills, plains, narrow valleys, and gorges. This varied relief generates a complex of microclimates and allows the presence of a mosaic of vegetation coverings, according to the altitudinal gradient, slope, and orientation of the slope. The vegetation cover is very variable, with the dominance of shrubs and trees in areas with altitudes lower than $3800 \mathrm{~m}$, the dominance of pasture in areas higher than $3800 \mathrm{~m}$, and dominance of Polylepis forests in areas above $4000 \mathrm{~m}$ of altitude. Also, where soil conditions allow, rural families perform diversified agricultural and livestock activities.

According to the Servicio Nacional de Meteorología e Hidrología [39], the basin has received an average rainfall of $518 \mathrm{~mm}$ per year for the past 30 years. In the dry seasonal period (April-September) the minimum precipitation was $9 \mathrm{~mm}$ a month in June and July, and in the rainy seasonal period (October-March) the maximum precipitation of the month was $143 \mathrm{~mm}$ in January and February. In the period from October to March, the average minimum temperature fluctuated between $2{ }^{\circ} \mathrm{C}$ and $7{ }^{\circ} \mathrm{C}$, and in the period from April to September, the average maximum temperature of the day fluctuated between $16^{\circ} \mathrm{C}$ and $17^{\circ} \mathrm{C}[39]$.

\subsection{Data Collection and Sampling}

We performed the data collection between July and August 2019, through visits and application of questionnaires [40]. During the fieldwork, we characterized the rural 
properties and evaluated the perception of the landowners and their families [40] about Polylepis forests and the ecosystem or environmental services provided by them. We also obtained data from secondary sources regarding censuses and statistics from the area, among other sources.

The main activities performed by the families in the studied communities were crops (potatoes, beans, peas, wheat) and livestock (sheep, cattle, alpacas, and llamas) on a small scale, mostly for subsistence. The community members use the Quecha language for local and Spanish for external communication and maintain their social coexistence within the framework of communal lifestyle and ancestral norms. Their cultural traditions are strongly connected to nature and farming activities. The community centers have rustic and precarious homes, provided with low-quality sanitation, education, and health services. Around $24 \%$ of the population use cesspool or septic tank, $76 \%$ live in adobe or brick houses, $14.6 \%$ have water supply from springs and rivers, $27.5 \%$ use firewood; the families have an average of 4 to 6 children [41].

We applied the questionnaires to families residing in 13 rural communities (Figure 2), selected based on a database containing the number of resident families provided by the "Instituto Nacional de Estatística e Informática" (INEI) [41] (Table 1). We selected the rural communities according to the following criteria: (i) easy access [38], although we suppose that it could affect negatively the amount of remnant forest, we did not have any expectation of it affecting the intention of restoring the forests; (ii) 10 or more resident families [40]; and (iii) being present in potential areas for occurrence Polylepis forests according to GEO GPS PERU [38].
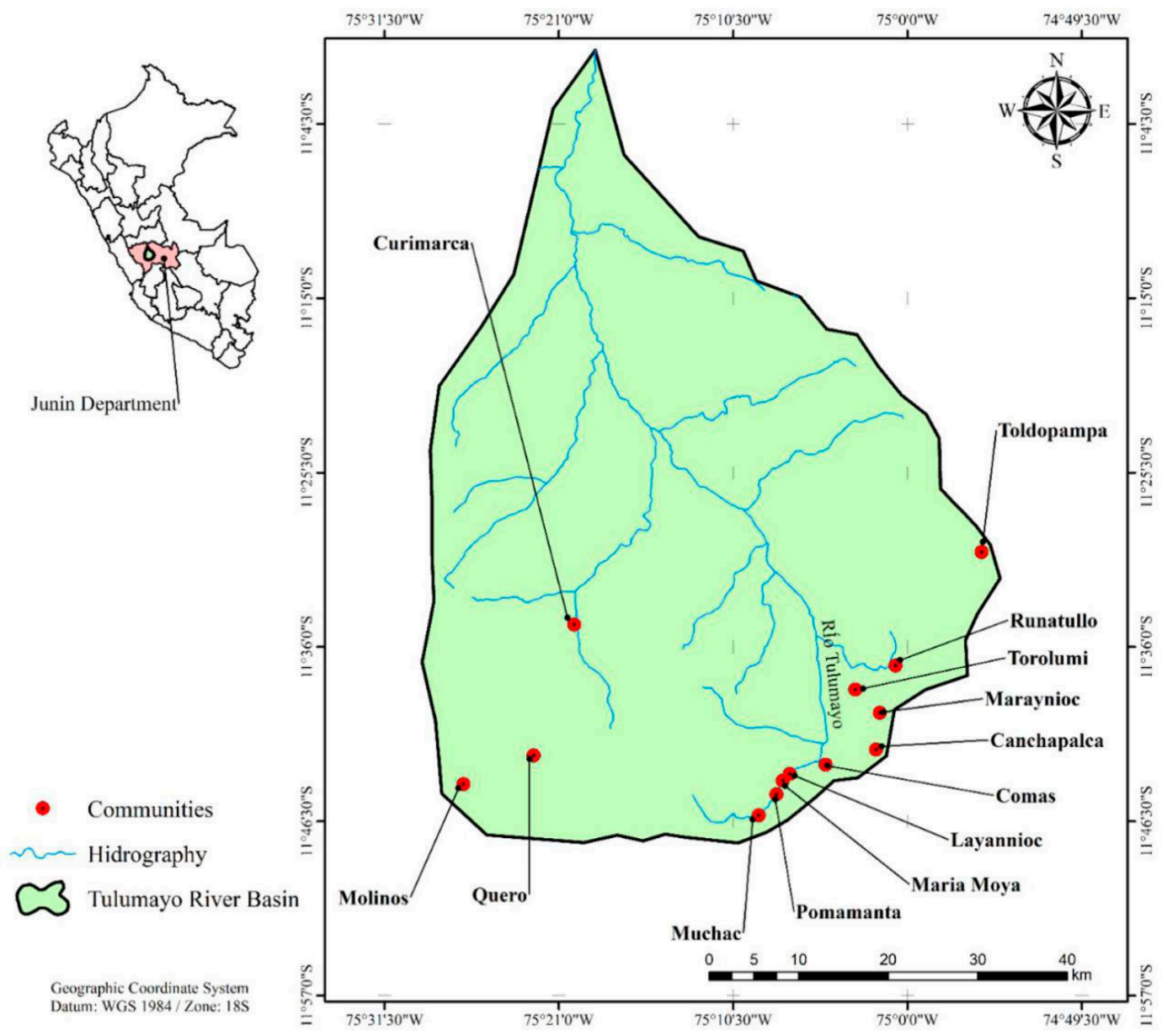

Figure 2. Location of the selected rural communities in the Tulumayo River Hydrographic Basin, Junin Department, Central Andes of Peru. Elaboration: Luciano Cavalcante de Jesus França. Source: GEO GPS PERÚ [38]. 
Table 1. Characteristics of the 13 selected rural communities

\begin{tabular}{ccccc}
\hline Communities & Natural Region $\mathbf{1}^{\text {Altitude }}$ & $\begin{array}{c}\text { Number of } \\
\text { (m.a.s.l.) }\end{array}$ & $\begin{array}{c}\text { Numpled } \\
\text { Families }\end{array}$ & $\begin{array}{c}\text { Resident } \\
\text { Families }\end{array}$ \\
\hline Muchac & Suni & 3897 & 15 & 33 \\
Comas & Quechua & 3303 & 20 & 347 \\
Runatullo & Quechua & 3477 & 15 & 103 \\
Torolumi & Suni & 3883 & 10 & 28 \\
Maraynioc & Suni & 3662 & 15 & 33 \\
Canchapalca & Suni & 3545 & 20 & 228 \\
Layannio & Quechua & 3437 & 10 & 28 \\
Maria Moya & Suni & 3518 & 10 & 13 \\
Pomamanta & Suni & 3629 & 15 & 76 \\
Molinos & Quechua & 3459 & 20 & 245 \\
Curimarca & Quechua & 3492 & 20 & 104 \\
Quero & Suni & 3896 & 15 & 86 \\
Toldopampa & Suni & 3673 & 15 & \\
\hline
\end{tabular}

Source: INEI [41]. ${ }^{1}$ Natural region: is a bioclimatic classification made by Pulgar Vidal [42] establishing eight natural regions. This classification is widely used to refer to altitude, climate, flora, fauna, and agricultural activities related to Quechua toponymy in Peru.

Within the 13 selected rural communities, we sampled randomly 20 resident families in the communities larger than 200 families (Comas, Canchapalca, Molinos, and Curimarca); 15 families in the communities ranging in size from 30-200 families (Muchac, Runatullo, Maraynioc, Pomamanta, Quero, and Tolodopampa); and 10 families in the communities below 30 families (Torolumi, Layannio, and Maria Moya). Only families that granted their permission to be questioned were sampled. If one or more previously selected families refused to be interviewed we would randomly select one or more families until we completed the number for that community. The total sample was 200 families.

\subsection{The Questionnaire}

The questionnaire was divided into four sections (Table A1). In the first section, we sought to characterize the rural families and their properties and the communities where the families were located. We collected data about family's head age, the number of people in the families, total area of the properties, crops area, pastures area, conserved Polylepis forest area, type of agricultural activity that represent the largest income source for the families, technical assistance received and dedication of the families to other nonagricultural activities.

In the second section, we focused on identifying the different kinds of Polylepis forest uses, such as the products used for consumption by families obtained in the forests and the importance of these products. For this, we asked the families about the importance of the products for them. Besides that, we evaluated the use of the forests for leisure activities, traditional and religious rituals (spiritual), and educational activities.

In the third section, we directed the questions to assess the intention of the families to restore the Polylepis forest areas in properties. We asked about the forest area that they would be willing to restore in the future, the difficulties they would imagine to be encountered during the process and the conditions needed for the restoration of these areas.

In the fourth section, we aimed to evaluate the families' knowledge about forest restoration, as well as their perception about the benefits provided by Polylepis forests in general, including the influences of the forests on the water sources of the properties, on the families' health and maintenance of biodiversity (fauna and flora). During the application of questionnaires, we classified the responses without the families being aware of the classes.

The researchers that applied the questionnaires were familiar with rural areas and understood the Quecha language. All 200 families explicitly consented to their participation in the study. The study was conducted following the Declaration of Helsinki. The research 
project (number CAAE 02466218.0.0000.5148) was submitted to Plataforma Brasil and approved by the Comissão de Ética em Pesquisa da Universidade Federal de Lavras (CEP/UFLA/Brazil) and by the Comissão Nacional de Ética em Pesquisa (CONEP/Brazil). Besides that, our research was preceded for a test with some Peruvian rural families by a team from the "Centro de Investigación en Alta Montaña del Instituto General de Investigación de la Universidad Nacional del Centro del Perú (CIAM/UNCP/Peru)", which allowed us to refine the questionnaires. Some of the questions and possible answers were adjusted to fit the reality of the local (practicability), and some were changed according to the understanding of the families regarding the subjects treated (comprehensibility).

\subsection{Data Analysis}

We performed the data analysis with 22 explanatory variables and 1 response variable. The response variable was the Polylepis forest area that the families intend to restore. We divided the explanatory variables into two categories: (i) socio-economic variables of the rural properties (15 variables): the community where the family lives, age of the family head, number of people in the family, total area of the property, crop area, pasture area, area with Polylepis forest, property largest income source, technical assistance received, dedication of the family to other non-agricultural activities, products for consumption obtained from the forest, the importance of these products, use of the forests for leisure activities, use of the forests for spiritual activities and use of the forests for educational activities; and (ii) family perception variables (7 variables): family's knowledge about forest restoration, perceived influence of the forests on the families' health, perceived influence of the forests on the water sources, perceived influence of the forests on the native fauna, perceived influence of the Polylepis forests on the native flora, difficulties to restore the forests, and conditions to restore the forests.

We performed the statistical analysis using a generalized linear mixed model (GLMM) and model selections taking the variable communities where the families live as a random factor (fixed effect) [43]. We logarithmized the values of the Polylepis forest areas that the families intend to restore (in hectares) before the analysis to address the premises of normality and homoscedasticity. Thus, the models were performed using the link log of the Gaussian family.

We selected the models using the second-order Akaike information criterion (AIC). The best competing models were indicated by a delta AICc $\leq 2$ [44]. From a multimodel inference approach, we calculated and compared standardized mean coefficients to determine the influence of the predictor variable on the response variable.

We build two different GLMMs. In the first GLMM, we analyzed the influence of the socioeconomic variables of the rural properties in the size of the Polylepis forest areas that the families intend to restore (hectares). In the second GLMM, we analyzed the influence of the family perception variables in the size of the Polylepis forest areas that they intend to restore (hectares). All statistical analyzes were performed on the Software R [45] with the following packages: Multcomp [46], lme4 [47], MuMIn [48], and ggplot2 [49] for the graphical analysis.

\section{Results}

The ages of the family's heads participating in our study varied between 20 and 92 years old, with a mean age of 45 years old. The families consisted of 1 to 10 people, with an average number of 4 people per family. Regarding the ways people acquired possession of their properties, the majority ( $53 \%$ ) acquired the property by comunero (Comunero: is the chief of the family registered in the peasant community, as a natural component and, as such, has the right to use community properties and the obligation to participate in the activities that the community requires.), approximately $30 \%$ of the families acquired the properties by inheritance, while only about $17 \%$ acquired them by purchase. The total properties area ranged between 0.2 to $19 \mathrm{ha}$, with an average area of $2.7 \mathrm{ha}$. The crop area ranged from 0 to $10 \mathrm{ha}$, with an average area of $1.43 \mathrm{ha}$. The pasture area ranged between 
0 to 10 ha, with an average area of 1.02 ha. Only $9 \%$ of the families received technical assistance in their properties most of the time from the public companies of technical assistance and rural extension of the Junin Department. Only 7\% of the landowners had other non-farming activities inside or outside the properties. The Polylepis forest area in the properties ranged from 0 to 5 ha (Figure 3A), with an average area of 0.2 ha. The Polylepis forest area that the families intend to restore in their properties in the future varied between 0 to 6 ha (Figure 3B), with an average area of 1.15 ha.

A)

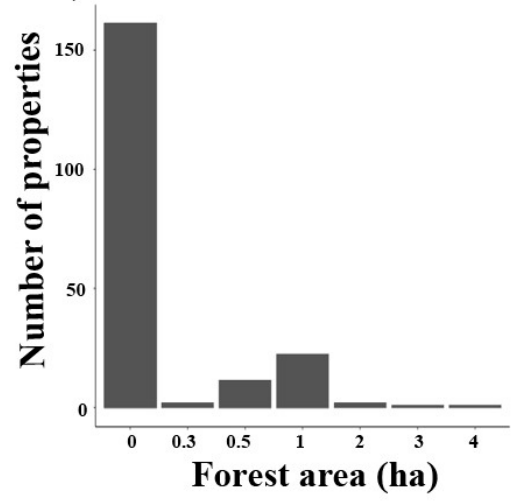

B)

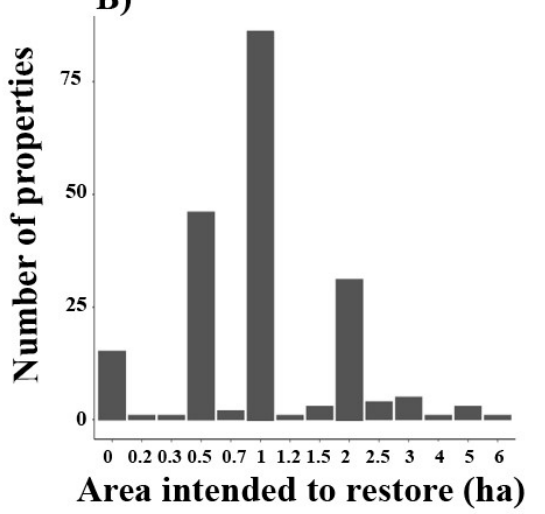

Figure 3. (A) Distribution of the Polylepis forest areas in the properties. (B) Distribution of the Polylepis forest areas that the families intend to restore in their properties.

\subsection{Socioeconomic Factors that Influenced the Intention to Restore Polylepis Forests in} the Properties

The vast majority of the families $(92.5 \%)$ had the intention to restore Polylepis forests in the properties. The size of the areas that the families intend to restore was positively affected by the variable related to the crops as the main source of income of the properties (Figure 4 and Table A2). The families' income was fairly balanced between crops and livestock activities. While in $53 \%$ of the properties, the livestock was considered the main source of income for the families, in the other $47 \%$, the crops were considered the main source of income.

\section{Area intended to restore (ha)}

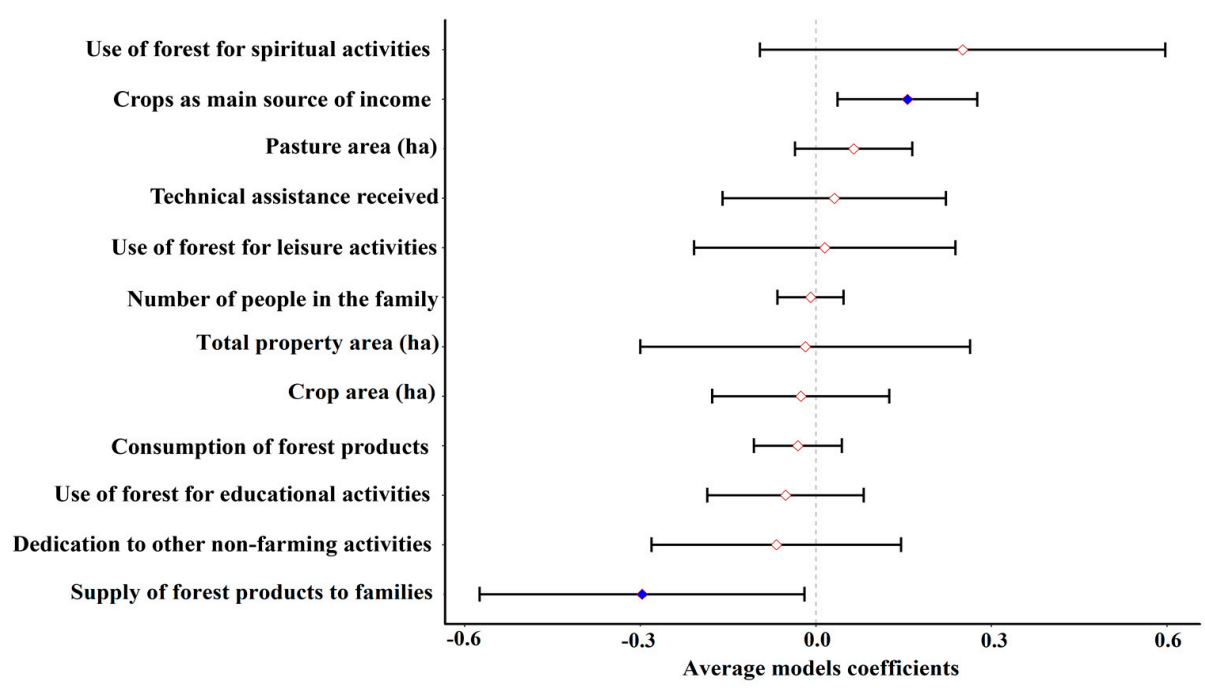

Figure 4. Average models coefficients analyzing the influence of the socioeconomic variables of the rural properties in the size of the Polylepis forest areas that the families intend to restore. 
On the other hand, the size of the areas that the families intended to restore was negatively affected by the variable related to the supply of forest products to the families (Figure 4 and Table A2). Regarding the use of Polylepis products, almost all of the families $(96 \%)$ extract firewood and wood from the forest for heating, building residences, and preparing food for the families' subsistence, while $4 \%$ do not use any products derived from the forest. Almost all of the families (96\%) also reported that the firewood and the wood obtained from the forests were very important for them.

Although the variables use of the forest for spiritual activities, pasture area, technical assistance received, use of the forest for leisure activities, the number of people in the family, total property area, crop area, consumption of forest products, use of the forest for educational activities, and dedication to other non-farming activities have appeared in the best models, none of them had a significant effect on the forests areas that the families intend to restore in the future. This indicates that they had little or no importance to explain the intention to restore forests in the properties of the region. The age of the family head did not influence the intention to restore Polylepis forest areas. In addition, although the vast majority of the families $(92.5 \%)$ had an intention to restore some areas of Polylepis forests in the properties the current existence or not of an area with such forest in the properties did not influence the intention to restore. This may be because well over three quarters $(3 / 4)$ of the sample properties did not have Polylepis forests.

\subsection{Family Perception Factors that Conditioned Their Intention to Restore the Polylepis Forests in Their Properties}

The size of the areas that the families intend to restore was positively affected by the families' knowledge about forest restoration and by the perceived influence of Polylepis forests in the water sources (Figure 5 and Table A3). The vast majority of the families $(91.5 \%)$ knew and understood the reasons and the importance of the forest restoration, just as the vast majority of them $(89 \%)$ had a positive perception about the influence of the Polylepis forests in the water sources in the properties.

\section{Area intended to restore (ha)}

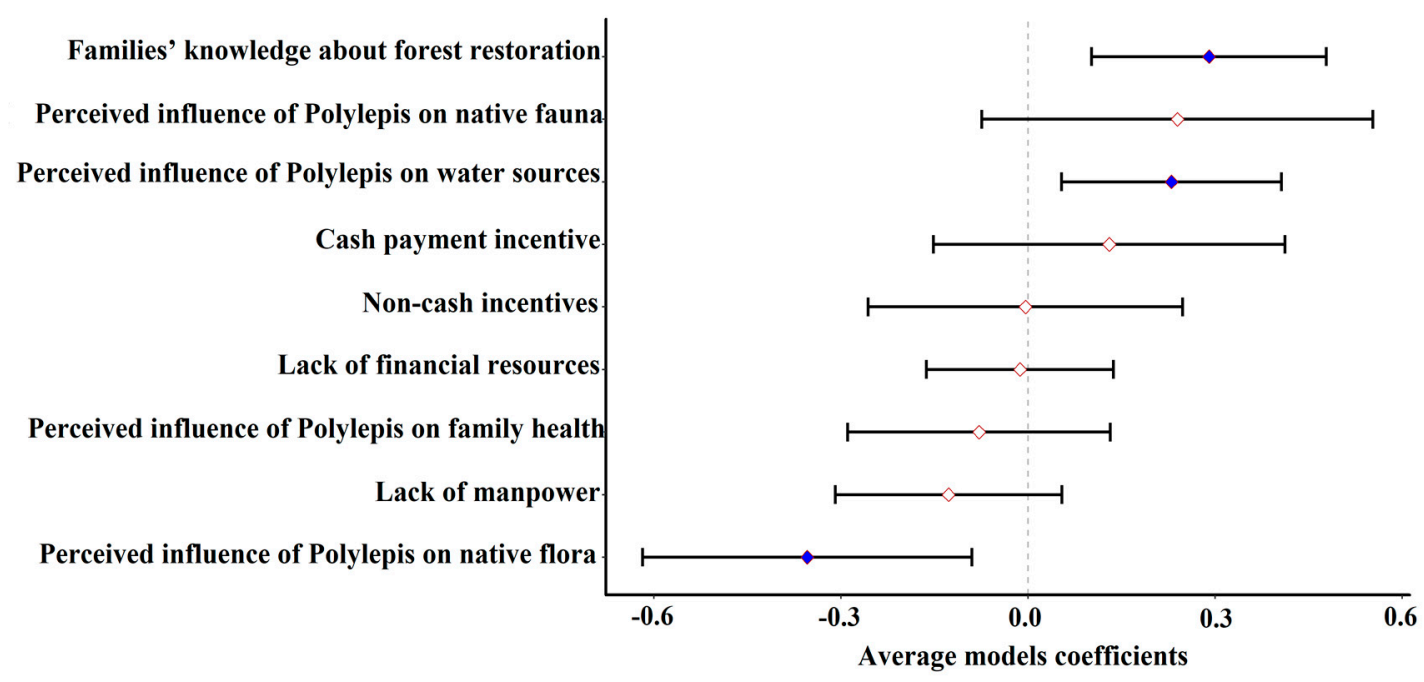

Figure 5. Average models coefficients analyzing the influence of the family perception variables in the size of the Polylepis forest areas that they intend to restore in the properties.

On the other hand, the size of the areas that the families intend to restore was negatively affected by the variable related to the perceived influence of Polylepis forests in the native flora (Figure 5 and Table A3). Despite this, the vast majority of the families (95.5\%) were aware of the positive effects of the Polylepis forests on the flora of the Andean Region. 
The variables the perceived influence of Polylepis forest on the native fauna, the perceived influence of Polylepis forest on family health, cash payment incentive and noncash incentives to restore the forests, and difficulties of lack of financial resources and lack of manpower did not have a significant effect on the forests areas that the families intend to restore. This indicates that these variables had little or no importance to explain the intention to restore the forest in the properties of the region.

\section{Discussion}

Our study revealed that the intention of the families to restore the Polylepis forest areas was affected both by socioeconomic factors of the rural properties and by family perception factors. Families more dependent on crops as the main source of income have a greater intention of restoring the Polylepis forest areas in the region, however, this intention reduces with the increase of family dependence on subsistence products supplied by Polylepis forests. The perception that Polylepis forests are important for the water supply in the properties and the families' knowledge about forest restoration had a positive relationship with their intention to restore the areas. On the other hand, this intention was negatively affected by their perception of Polylepis forests as important for the conservation of native flora.

The positive correlation between restoration intention with higher income from the crops and the negative correlation with the dependence of Polylepis forests' products contradicted our original expectations. The weak correlation between these two socioeconomic factors suggests that both the factors are independent and families more dependent on crops are not the ones less dependent on Polylepis forest products.

The positive correlation between restoration intention and the dependence on agricultural products is possibly linked to the fact that such properties have a higher technological level. Such families possibly have a better educational level, and deeper knowledge of the importance of restoration and its positive consequences for the property's ecological and economic sustainability [37,50-52], resulting in a higher intention to restore forest areas.

On the other hand, the families that are more dependent on the Polylepis forests are likely to have a lower technological level (they are more dependent on extractivist activities) and a lower financial level $[52,53]$ and, therefore, have a smaller intention and conditions to restore forest areas. In addition, the families which are more dependent on the Polylepis products have probably a larger proportion of their properties with forest and, therefore, have no intention to occupy more areas of the property with it. In such a situation, higher forest cover would compete with their other economic activities. At Liwonde in Malawi, for example, Jumbe and Angelsen [51] related similar results to the families' unwillingness to participate in a forest restoration activity where the forests were important suppliers of products for their subsistence. However, the same author [51] found that the high dependence on the forest induces higher rates of participation in forest restoration at Chimaliro in the same country. Besides that, in contradiction to our results, Lise [50], Oli and Treue [52], Dolisca et al. [54] argued that a high dependence on the forest increases people's voluntary participation in forest restoration activities. Jumbe and Angelsen [51], Maskey et al. [53], Dolisca et al. [54], and Coulibaly-Lingani et al. [55] found that the degree to which users of common forest resources participate in forest restoration activity is determined by the benefits obtained from doing so. Therefore, the relationship between the dependence of forest products and the intention of restoring the forest seems complex and highly dependent on local and particular conditions.

Both the knowledge about the importance of the Polylepis forests for water supply, as the technical knowledge about forest restoration had a positive impact on the intention of restoring the forests, agreeing with our original hypotheses. Certainly, the relative rainfall shortage in the Central Andes is strongly connected to the positive connection between the role of Polylepis forest for water supply and the families' intention of restoring the forest. This perception is supported by concrete data about the influence of the Polylepis forests on water availability in some regions of the Andes $[6,19,56,57]$. However, for the connection 
between the intention of forest restoration and the knowledge about restoring degraded areas, it is hard to know which one is the cause and which one is the effect.

Whatever is the answer for this rather circular last issue, the positive effects of the knowledge about the importance of the forest for the water resources as well as the technical knowledge about forest restoration in the intention of restoration point out that investment in education about the environmental services provided by the forest and, also, in the techniques necessary for its restoration may have a positive effect on the return of Polylepis forests to the Andean region. Likewise, some authors-for example, Lise [50], Oli and Treue [52], Dolisca et al. [54], Torgler et al. [58], and Gebregziabher and Soltani [59] revealed that the family heads' attitudes towards the forestry activities were influenced by the families' knowledge about these areas. The supposed causal reason is that people with a better education level are more aware of the potential benefits that derive from collective and sustainable management of forests [54] and have stronger environmental attitudes $[58,60]$. This means that education and knowledge can bear fruit in the restoration and protection of forests.

On the other hand, we understand that the negative connection between the families' intention to restore Polylepis areas and their perception about the importance of Polylepis for the maintenance of the plants in the region may be an unwanted result of the Laws no. 26839 of 1997 and no. 29763 of 2015 in Peru, which provide for the conservation and sustainable use of the native vegetation $[61,62]$. Therefore, possibly, the families that perceive a positive influence of the Polylepis forests in the local flora, also resist restoring forest areas in properties fearing turning parts of the properties unavailable for their use. In addition, in consonance with Jumbe and Angelsen [51] at Liwonde in Malawi, these families are possibly those most dependent on forest products. Such families may not be able to afford the costs of restricted forest use, in the interest of conservation. As such, they abstain from participating in forest restoration.

The gender of heads of households can possibly affect their intention to restore forests in rural communities. Unfortunately, this variable was removed from the questionnaire and we were not able to recover it. However, we know that, in Peru, most household heads in the rural communities are male, and that is true for our sample too, although we do not have the data. In addition, our results may partially reflect the social, environmental, and cultural specificities of the place of study (as described in the methods section). Therefore, other studies about how socioeconomic conditions of the Andean rural properties and the landowners' intention to restore Polylepis forests in their properties are necessary for other regions of the Andes. The great extent of the Polylepis forest distribution throughout the Andean mountain range comprises a large ethnic, social, and economic diversity [15].

\section{Conclusions}

Our study showed that the intention to restore the Polylepis forest seems to be closely linked to the greater importance of the crops in the economy of the property, the perception that the Polylepis forest is important for the water supply, and the existence of knowledge about forests restoration. All of these factors point out that the properties where the chances of restoration of the Polylepis forests are greater are those that have a higher technological level (greater investment in agricultural production) and where the educational level is better. Thus, investment in improving the productivity of the properties and in the education of their landowners should increase the success of eventual programs for restoration of Polylepis forests.

Author Contributions: Conceptualization, L.J. and E.v.d.B.; Methodology, L.J., E.v.d.B., R.M.Y.C. and M.A.-A.; Software, M.V.P. and F.F.d.S.; Validation, L.J. and E.v.d.B.; Formal analysis, M.V.P. and F.F.d.S.; Investigation, L.J. and R.M.Y.C.; Resources, R.M.Y.C. and M.A.-A.; Data curation, L.J. and E.v.d.B.; Writing—original draft preparation, L.J. and E.v.d.B.; Writing—review and editing, L.J. and E.v.d.B.; Visualization, L.J., E.v.d.B., M.V.P. and F.F.d.S.; Supervision, R.M.Y.C. and M.A.-A.; Project administration, R.M.Y.C., E.v.d.B., L.J. and M.A.-A.; Funding acquisition, R.M.Y.C. All authors have read and agreed to the published version of the manuscript. 
Funding: This research was funded by "Instituto General de Investigación de la Universidad Nacional del Centro del Perú (UNCP/Perú), Code UNESCO 3005.99”, “Coordenação de Aperfeiçoamento de Pessoal de Nível Superior do Brasil (CAPES/Brasil)", "Conselho Nacional de Desenvolvimento Científico e Tecnológico (CNPq/Brasil)", and "Fundação de Amparo à Pesquisa do Estado de Minas Gerais (FAPEMIG/Brasil)".

Institutional Review Board Statement: The study was conducted according to the guidelines of the Declaration of Helsinki, and approved by the Institutional Review Board of Federal University of Lavras (CEP/UFLA/Brazil) and by the National Research Ethics Committee (CONEP/Brazil) (protocol code 02466218.0.0000.5148 and date of approval 22 February2019).

Informed Consent Statement: Informed consent was obtained from all subjects involved in the study.

Data Availability Statement: The data are not publicly available due to the rules of the Research Ethics Committee of the Federal University of Lavras (CEP/UFLA/Brazil) and the National Research Ethics Committee (CONEP/Brazil).

Acknowledgments: We thank the team at the "Centro de Investigación en Alta Montaña (CIAM/ UNCP/Perú)" for their support and help in collecting data in the field and data tabulation.

Conflicts of Interest: The authors declare no conflict of interest. The funders had no role in the design of the study; in the collection, analyses, or interpretation of data; in the writing of the manuscript, or in the decision to publish the results.

\section{Appendix A}

Table A1. The questionnaire divided into four sections.

\begin{tabular}{l} 
List of the Questions \\
\hline Section 1 \\
\hline Community: \\
Age of the family head: \\
Number of people in the family: \\
Total area of the property (ha): \\
Crop area (ha): \\
Pasture area (ha): \\
Polylepis forested area (ha) in the property: \\
Types of agricultural activities performed on the property: \\
In general, what is the main source of income for the property? R: \\
Do you receive technical assistance on your property? R: (a) Yes (b) No \\
Do you engage in other non-agricultural activities? R: (a) Yes (b) No \\
\hline Section 2 \\
Are there some products for consumption or sale that are obtained from the Polylepis forests? R: \\
(a) Yes (b) No. If so, which products do you use? R: \\
How would you rate the importance of the products from the Polylepis forests? R: \\
Do you use the Polylepis forests for leisure activities? R: (a) Yes (b) No \\
Do you use the Polylepis forests for spiritual activities? R: (a) Yes (b) No \\
Do you use the Polylepis forests for education activities? R: (a) Yes (b) No \\
\hline Section 3 \\
\hline Do you intend and are you willing to restore the Polylepis forests in your property? R: (a) Yes (b) \\
No. If so, how many hectares (ha) of forests do you want to restore? R: \\
What are the conditions for you to restore the Polylepis forests? R: \\
What would be the greatest difficulties in restoring these forests in the property or in the \\
community? R: \\
\hline
\end{tabular}


Table A1. Cont.

\begin{tabular}{l} 
List of the Questions \\
\hline Section 4 \\
\hline Do you know and understand why you should restore the forests in general? R: (a) Yes (b) No. If \\
so, why? R: \\
Do you believe that the Polylepis forests can influence the maintenance of water sources on the \\
properties? R: (a) Yes (b) No. If so, how? R: \\
In your opinion, can the Polylepis forests influence family health? R: (a) Yes (b) No. If so, how? R: \\
Can the Polylepis forests influence animals' lives? R: (a) Yes (b) No. If so, how does it influence? R: \\
Can the Polylepis forests influence other plants? R: (a) Yes (b) No. If so, how? R: \\
\hline
\end{tabular}

Table A2. Influence of the socioeconomic variables of the rural properties on the size of the Polylepis forest areas that the families intend to restore.

\begin{tabular}{|c|c|c|c|c|c|c|}
\hline & Estimate & Std. Error & Adjusted SE & $z$ Value & $\operatorname{Pr}(>|z|)$ & \\
\hline (Intercept) & 0.912137 & 0.184819 & 0.185507 & 4.917 & $9.0 \times 10^{-7}$ & $* * *$ \\
\hline Use of forest for spiritual activities & 0.260701 & 0.178283 & 0.179392 & 1.453 & 0.1462 & \\
\hline Crops as main source of income & 0.157103 & 0.060811 & 0.061181 & 2.568 & 0.0102 & * \\
\hline Pasture area (ha) & 0.067048 & 0.055749 & 0.056013 & 1.197 & 0.2313 & \\
\hline Technical assistance received & 0.025408 & 0.098531 & 0.099142 & 0.256 & 0.7977 & \\
\hline Use of forest for leisure activities & 0.01834 & 0.115829 & 0.116521 & 0.157 & 0.8749 & \\
\hline Number of people in the family & -0.009518 & 0.029087 & 0.029269 & 0.325 & 0.745 & \\
\hline Total property area (ha) & -0.016292 & 0.081806 & 0.082096 & 0.198 & 0.8427 & \\
\hline Crop area (ha) & -0.026284 & 0.042354 & 0.042578 & 0.617 & 0.537 & \\
\hline Consumption of forest products & -0.034774 & 0.145676 & 0.146554 & 0.237 & 0.8124 & \\
\hline Use of forest for educational activities & -0.053444 & 0.06954 & 0.069968 & 0.764 & 0.445 & \\
\hline Dedication to other non-farming activities & -0.061796 & 0.109381 & 0.110069 & 0.561 & 0.5745 & \\
\hline Supply of forest products to families & -0.295435 & 0.141874 & 0.142764 & 2.069 & 0.0385 & * \\
\hline
\end{tabular}

Significant codes: 0 ‘*** $0.01^{\star * \prime} 0.05{ }^{\prime \prime} 0.1^{\prime \prime} 1$.

Table A3. Influence of the perception variables of the rural families in the size of the Polylepis forest areas that they intend to restore in the properties.

\begin{tabular}{|c|c|c|c|c|c|c|}
\hline & Estimate & Std. Error & Adjusted SE & $z$ Value & $\operatorname{Pr}(>|z|)$ & \\
\hline (Intercept) & 0.532686 & 0.240285 & 0.241574 & 2.205 & 0.02745 & * \\
\hline Families' knowledge about forest restoration & 0.290089 & 0.095311 & 0.095904 & 3.025 & 0.00249 & ** \\
\hline Perceived influence of Polylepis on native fauna & 0.23946 & 0.159009 & 0.160012 & 1.497 & 0.13452 & \\
\hline Perceived influence of Polylepis on water sources & 0.23003 & 0.08927 & 0.08983 & 2.561 & 0.01045 & * \\
\hline Cash payment incentive & 0.130173 & 0.142859 & 0.143768 & 0.905 & 0.36523 & \\
\hline Non-cash incentives & -0.004168 & 0.127792 & 0.128606 & 0.032 & 0.97415 & \\
\hline Lack of financial resources & -0.012904 & 0.076041 & 0.076525 & 0.169 & 0.86609 & \\
\hline Perceived influence of Polylepis on family health & -0.078606 & 0.106835 & 0.10751 & 0.731 & 0.46468 & \\
\hline Lack of manpower & -0.127448 & 0.092111 & 0.092697 & 1.375 & 0.16916 & \\
\hline Perceived influence of Polylepis on native flora & -0.354188 & 0.133911 & 0.13472 & 2.629 & 0.00856 & ** \\
\hline
\end{tabular}

Significant codes: $0.001^{\prime * * \prime} 0.01^{\prime * \prime} 0.05^{\prime} .{ }^{\prime} 0.1^{\prime \prime} 1$.

\section{References}

1. Kräuchi, N.; Brang, P.; Schönenberger, W. Forests of mountainous regions: Gaps in knowledge and research needs. For. Ecol. Manag. 2000, 132, 73-82. [CrossRef]

2. Beniston, M. Climatic Change in Mountain Regions: A Review of Possible Impacts. Adv. Glob. Chang. Res. 2003, 15, 5-31. [CrossRef]

3. Martin, M.F.; Gratzer, G.; Alemayehu Duguma, L.; Kohler, T.; Maselli, D.; Romeo, R. Mountain Forests in a Changing WorldRealizing Values, Adressing Challenges; Food and Agriculture Organization of the United Nations (FAO/MPS) and Swiss Agency for Development and Cooperation: Rome, Italy, 2011.

4. Körner, C. The Green Cover of Mountains in a Changing Environment. In Global Change and Mountain Regions; Springer Science: Dordrecht, The Netherlands, 2005; Volume 23, pp. 367-375. 
5. Sidle, R.C.; Ziegler, A.D.; Negishi, J.N.; Nik, A.R.; Siew, R.; Turkelboom, F. Erosion processes in steep terrain-Truths, myths, and uncertainties related to forest management in Southeast Asia. For. Ecol. Manag. 2006, 224, 199-225. [CrossRef]

6. Kessler, M. Bosques de Polylepis. Botánica Económica de los Andes Centrales; Universidad Mayor de San Andrés: La Paz, Bolívia, 2006.

7. Burgess, N.D.; Butynski, T.M.; Cordeiro, N.J.; Doggart, N.H.; Fjeldså, J.; Howell, K.M.; Kilahama, F.B.; Loader, S.P.; Lovett, J.C.; Mbilinyi, B.; et al. The biological importance of the Eastern Arc Mountains of Tanzania and Kenya. Biol. Conserv. 2007, 134, 209-231. [CrossRef]

8. Menegon, M.; Doggart, N.; Owen, N. The Nguru mountains of Tanzania, an outstanding hotspot of herpetofaunal diversity. Acta Herpetol. 2008, 3, 107-127.

9. Sylvester, S.P.; Heitkamp, F.; Sylvester, M.D.P.V.; Jungkunst, H.F.; Sipman, H.J.M.; Toivonen, J.M.; Inca, C.A.G.; Ospina, J.C.; Kessler, M. Relict high-Andean ecosystems challenge our concepts of naturalness and human impact. Sci. Rep. 2017, 7, 1-13. [CrossRef] [PubMed]

10. Beiderwieden, E.; Wrzesinsky, T.; Klemm, O. Chemical characterization of fog and rain water collected at the eastern Andes cordillera. Hydrol. Earth Syst. Sci. 2005, 9, 185-191. [CrossRef]

11. Molles, M. Ecology: Concepts and Applications; McGraw-Hill Education: New York, NY, USA, 2015. Available online: https: / / lib.hpu.edu.vn/handle/123456789/32423 (accessed on 26 December 2020).

12. Renison, D.; Morales, L.; Cuyckens, G.É.; Sevillano, C.S.; Amaya, D.M.C. Ecología y conservación de los bosques y arbustales de Polylepis: ¿qué sabemos y qué ignoramos? Ecología Austral 2018, 28, 163-174. [CrossRef]

13. Buytaert, W.; Célleri, R.; De Bièvre, B.; Cisneros, F.; Wyseure, G.; Deckers, J.A.; Hofstede, R. Human impact on the hydrology of the Andean páramos. Earth Sci. Rev. 2006, 79, 53-72. [CrossRef]

14. Brehm, G.; Homeier, J.; Fiedler, K.; Kottke, I.; Illig, J.; Nöske, N.M.; Werner, F.A.; Breckle, S.W. Mountain Rain Forests in Southern Ecuador as a Hotspot of Biodiversity—Limited Knowledge and Diverging Patterns. In Cave Ecology; Springer: Berlin/Heidelberg, Germany, 2008; Volume 198, pp. 15-23.

15. Zutta, B.R.; Rundel, P.W.; Saatchi, S.; Casana, J.D.; Gauthier, P.G.; Soto, A.; Velazco, Y.; Buermann, W. Prediciendo la distribución de Polylepis: Bosques Andinos vulnerables y cada vez más importantes. Rev. Peru. Biol. 2012, 19, 205-212. [CrossRef]

16. Zutta, B.R.; Rundel, P.W. Modeled Shifts in Polylepis Species Ranges in the Andes from the Last Glacial Maximum to the Present. Forests 2017, 8, 232. [CrossRef]

17. Bruijnzeel, L.A. Hydrology of tropical montane cloud forests: A reassessment. Land Use Water Resour. Res. 2001, 1, 1.1-1.18.

18. Healey, J.; Hamilton, L.S.; Juvik, J.O.; Scatena, F.N. Tropical Montane Cloud Forests. Mt. Res. Dev. 1997, 17, 96. [CrossRef]

19. Kessler, M.; Toivonen, J.M.; Sylvester, S.P.; Kluge, J.; Hertel, D. Elevational patterns of Polylepis tree height (Rosaceae) in the high Andes of Peru: Role of human impact and climatic conditions. Front. Plant Sci. 2014, 5, 194. [CrossRef] [PubMed]

20. Young, K.; León, B. Tree-line changes along the Andes: Implications of spatial patterns and dynamics. Philos. Trans. R. Soc. B Biol. Sci. 2006, 362, 263-272. [CrossRef]

21. Navarro, G.; Molina, J.A.; De La Barra, N. Classification of the high-Andean Polylepis forests in Bolivia. Plant Ecol. 2005, 176, 113-130. [CrossRef]

22. Cuyckens, G.; Christie, D.; Domic, A.; Malizia, L.; Renison, D. Climate change and the distribution and conservation of the world's highest elevation woodlands in the South American Altiplano. Glob. Planet. Chang. 2016, 137, 79-87. [CrossRef]

23. Navarro, G.; Arrázola, S.; Balderrama, J.A.; Ferreira, W.; De la Barra, N.; Antezana, C.; Gómez, I.; Mercado, M. Diagnóstico del estado de conservación y caracterización de los bosques de Polylepis en Bolivia y su avifauna. Revista Boliviana de Ecología y Conservación Ambiental 2010, 28, 1-35.

24. Renison, D.; Cuyckens, G.A.E.; Pacheco, S.; Guzmán, G.F.; Grau, H.R.; Marcora, P.I.; Robledo, G.L.; Cingolani, A.M.; Dominguez, J.; Landi, M.A.; et al. Distribución y estado de conservación de las poblaciones de árboles y arbustos del género Polylepis (Rosaceae) en las montañas de Argentina. Ecol. Austral 2013, 23, 27-36. Available online: http://hdl.handle.net/11336/1419 (accessed on 26 December 2020). [CrossRef]

25. Hoch, G.; Körner, C. Growth, demography and carbon relations of Polylepis trees at the world's highest treeline. Funct. Ecol. 2005, 19, 941-951. [CrossRef]

26. Herzog, S.K.; Kessler, M.; Bach, K. The elevational gradient in Andean bird species richness at the local scale: A foothill peak and a high-elevation plateau. Ecography 2005, 28, 209-222. [CrossRef]

27. Cingolani, A.M.; Renison, D.; Tecco, P.A.; Gurvich, D.E.; Cabido, M. Predicting cover types in a mountain range with long evolutionary grazing history: A GIS approach. J. Biogeogr. 2008, 35, 538-551. [CrossRef]

28. Sylvester, S.P.; Sylvester, M.D.P.V.; Kessler, M. The world's highest vascular epiphytes found in the Peruvian Andes. Alp. Bot. 2014, 124, 179-185. [CrossRef]

29. Camel, V.; Arizapana-Almonacid, M.; Pyles, M.; Galeano, E.; Quispe-Melgar, H.R.; Ninanya-Parra, Z.; Ames-Martínez, F.N.; Requena-Rojas, E.; Kessler, M. Using dendrochronology to trace the impact of the hemiparasite Tristerix chodatianus on Andean Polylepis trees. Plant Ecol. 2019, 220, 873-886. [CrossRef]

30. Winston, R.R. Historia de los Pueblos de Yauyos; R\&R Ediciones: Lima, Perú, 2002.

31. Kessler, M.; Schmidt-Lebuhn, A.N. Taxonomical and distributional notes on Polylepis (Rosaceae). Org. Divers. Evol. 2006, 6, 67-69. [CrossRef]

32. Mendoza, W.; Cano, A. Diversidad del género Polylepis (Rosaceae, Sanguisorbeae) en los Andes peruanos. Rev. Peru. Biol. 2011, 18, 197-200. [CrossRef] 
33. Segovia-Salcedo, M.C.; Domic, A.; Boza, T.; Kessler, M. Situación taxonómica de las especies del género Polylepis. Implicancias para los estudios ecológicos, la conservación y la restauración de sus bosques. Ecol. Austral 2018, 28, 188-201. [CrossRef]

34. IUCN. The IUCN Red List of Threatened Species. 2020. Available online: http://www.iucnredlist.org/ (accessed on 15 September 2008).

35. Gareca, E.E.; Hermy, M.; Fjeldså, J.; Honnay, O. Polylepis woodland remnants as biodiversity islands in the Bolivian high Andes. Biodivers. Conserv. 2010, 19, 3327-3346. [CrossRef]

36. Niemeyer, J.; Barros, F.S.; Silva, D.S.; Crouzeilles, R.; Vale, M.M. Planning forest restoration within private land holdings with conservation co-benefits at the landscape scale. Sci. Total Environ. 2020, 717, 135262. [CrossRef]

37. Soe, K.T.; Yeo-Chang, Y. Perceptions of forest-dependent communities toward participation in forest conservation: A case study in Bago Yoma, South-Central Myanmar. For. Policy Econ. 2019, 100, 129-141. [CrossRef]

38. GEO GPS PERÚ. Base de datos 2019. Available online: https://www.geogpsperu.com/ (accessed on 11 June 2019).

39. SENAMHI-Servicio Nacional de Meteorología e Hidrología. Datos Hidrometeorológicos a Nivel Nacional; Estación Meteorológica del Distrito de Comas: Junin, Peru, 2019. Available online: https://www.senamhi.gob.pe/?\&p=estaciones (accessed on 11 December 2019).

40. Boni, V.; Quaresma, S.J. Aprendendo a entrevistar: Como fazer entrevistas em Ciências Sociais. Em Tese 2005, 2, 68-80.

41. INEI-Instituto Nacional de Estadística e Informática. Censos Nacionales 2017: XII de Población, VII de Vivienda y III de Comun-idades Indígenas; Directorio Nacional de Centros Poblados: Junin, Peru, 2017. Available online: https://www.inei.gob.pe/media/ MenuRecursivo/publicaciones_digitales/Est/Lib1541/index.htm?fbclid=IwAR0GtL-sr4_0I4RiWP4i7ABpjts3c5pJ5rsuQE6 eNybLCiuN_dmGzgXb_A (accessed on 30 March 2019).

42. Pulgar Vidal, J. Geografia del Perú: Las Ocho Regiones Naturales, la Regionalización Transversal, la Sabiduría Ecológica Tradicional; Peisa: Lima, Peru, 1996.

43. Bolker, B.M.; Brooks, M.E.; Clark, C.; Geange, S.W.; Poulsen, J.R.; Stevens, M.H.H.; White, J.-S.S. Generalized linear mixed models: A practical guide for ecology and evolution. Trends Ecol. Evol. 2009, 24, 127-135. [CrossRef] [PubMed]

44. Burnham, K.P.; Anderson, D.R. Model Selection and Multimodel Inference: A Practical Information-Theoretic Approach, 2nd ed.; Springer: New York, NY, USA, 2002; Volume 26, p. 488.

45. R Core Team. R. A Language and Environment for Statistical Computing; R Foundation for Statistical Computing: Vienna, Austria, 2015. Available online: http:/ / www.R-project.org/ (accessed on 26 December 2020).

46. Hothorn, T.; Bretz, F.; Westfall, P.; Heiberger, R.M.; Schuetzenmeister, A.; Scheibe, S.; Hothorn, M.T. Package "Multcomp": Simultaneous Inference in General Parametric Models; Project for Statistical Computing: Vienna, Austria, 2016.

47. Bates, D.; Maechler, M.; Bolker, B.; Walker, S.; Christensen, R.H.B.; Singmann, H.; Dai, B. R Package "lme4": Linear Mixed-Effects Models Using Eigen and S4, Version 1.1-7. 2014. Available online: http:/ /CRAN.R-project.org/package=lme4 (accessed on 26 December 2020).

48. Barton, K. Package “MuMIn”: Multi-Model Inference. R Package, Version 1.15.6. 2016. Available online: https:/ / cran.r-project. org/web/packages/MuMIn/index (accessed on 26 December 2020).

49. Wickham, H.; Francois, R.; Henry, L.; Müller, K. Dplyr: A Grammar of Data Manipulation; R Package Version 0.4.3; R Foundation for Statistical Computing: Vienna, Austria, 2015. Available online: https:/ /CRAN.R-project.org/package=dplyr (accessed on 26 December 2020).

50. Lise, W. Factors influencing people's participation in forest management in India. Ecol. Econ. 2000, 34, 379-392. [CrossRef]

51. Jumbe, C.B.L.; Angelsen, A. Forest dependence and participation in CPR management: Empirical evidence from forest comanagement in Malawi. Ecol. Econ. 2007, 62, 661-672. [CrossRef]

52. Oli, B.; Treue, T. Determinants of participation in Community Forestry in Nepal. Int. For. Rev. 2015, 17, 311-325. [CrossRef]

53. Maskey, V.; Gebremedhin, T.G.; Dalton, T.J. Social and cultural determinants of collective management of community forest in Nepal. J. For. Econ. 2006, 11, 261-274. [CrossRef]

54. Dolisca, F.; Carter, D.R.; McDaniel, J.M.; Shannon, D.A.; Jolly, C.M. Factors influencing farmers' participation in forestry management programs: A case study from Haiti. For. Ecol. Manag. 2006, 236, 324-331. [CrossRef]

55. Coulibaly-Lingani, P.; Savadogo, P.; Tigabu, M.; Odén, P.C. Factors influencing people's participation in the forest management program in Burkina Faso, West Africa. For. Policy Econ. 2011, 13, 292-302. [CrossRef]

56. Garcia-Nunez, C.; Rada, F.; Boero, C.; Gonzalez, J.; Gallardo, M.; Azocar, A.; Liberman-Cruz, M.; Hilal, M.; Prado, F. Leaf Gas Exchange and Water Relations in Polylepis tarapacana at Extreme Altitudes in the Bolivian Andes. Photosynthetica 2004, 42, 133-138. [CrossRef]

57. Fjeldså, J. Polylepis forests-vestiges of a vanishing ecosystem in the Andes. Ecotropica 2002, 8, 111-123.

58. Torgler, B.; García-Valiñas, M.A.; MacIntyre, A. Participation in environmental organizations: An empirical analysis. Environ. Dev. Econ. 2011, 16, 591-620. [CrossRef]

59. Gebregziabher, D.; Soltani, A. Exclosures in people's minds: Perceptions and attitudes in the Tigray region, Ethiopia. For. Policy Econ. 2019, 101, 1-14. [CrossRef]

60. Doughty, C.A. Building climate change resilience through local cooperation: A Peruvian Andes case study. Reg. Environ. Chang. 2015, 16, 2187-2197. [CrossRef] 
61. Peruano, E. Ley Sobre La Conservación y Aprovechamiento Sostenible de la Diversidad Biológica (Ley N 26839). Normas Leg. 1997, 15, 151057.

62. Ambiental, A. Se aprueban los 4 reglamentos de la Ley Forestal y de Fauna silvestre (ley N ${ }^{\circ}$ 29763). 2015. Available online: http:/ / www.actualidadambiental.pe (accessed on 3 February 2020). 